\title{
JUDICIAL REVIEW OF THE RIGHT TO HEALTH AND its Progressive ReAlisation: \\ The Case of the Constitutional Court of Peru
}

\author{
Illari Aragon Noriega"
}

\begin{abstract}
Notions of justice have historically been attributed to the range of civil and political rights, most prominently set forth in the International Covenant on Civil and Political Rights (ICCPR). The ICCPR imposes upon states clear obligations to respect and guarantee these rights to everyone within their respective jurisdictions; with the result being that civil and political rights are unquestionably the subject of judicial adjudication at the national and international level. A somewhat different approach has been taken to economic, social and cultural rights, often referred to as second generation rights. These are often associated with ideas of 'aspirational' policy goals, rather than of rights that impose specific and judicially enforceable obligations. Nonetheless, in some jurisdictions, constitutional litigation has proved to be an effective avenue for the realization of economic, social and cultural rights, and particularly of the human right to health.

The purpose of this paper is to analyze the judicial review undertaken by the Constitutional Court of Peru of the human right to health, and particularly the notion of progressive realisation. Through interpretation carried out in four different cases, this national court has examined the scope and contours of the human right to health, analyzing elements of its normative content, and elucidating in concrete cases the often vaguely understood principle of progressive realisation. As will be demonstrated in this paper, the Peruvian Constitutional Court has contributed to the consolidation of the case for judicial enforcement of the right to health in domestic law, joining the efforts of a handful of other domestic courts in the world which, through innovative approaches, have taken steps forward in clarifying the content of this right and the parameters for its implementation in line with international human rights law.
\end{abstract}

\section{A. INTRODUCTION}

As stated by Mr Justice Goldstone, 'The enforcement of economic, social and cultural rights represents a new and controversial area of judicial

\footnotetext{
" The author would like to thank Marisol Pérez Tello and Francisco Morales Saravia for their invaluable support of her research into this topic. She would also like to express her gratitude to Professor John Hatchard who co-taught the LLM module on Law and Governance in the Developing World for which this paper was originally submitted.
} 
intervention'. ' While notions of justiciability have traditionally centered on civil and political rights, economic, social and cultural rights tend to be associated with political commitments and developmental ideals rather than norms which impose determinate obligations on states. Accordingly, economic, social and cultural rights 'have suffered from a lack of judicial and political acceptance'. ${ }^{2}$ Nonetheless, the traditional tendency to approach these rights, among them the right to health, from a thematic perspective and within the domain of public policy does not necessarily mean that they are not judicially enforceable rights. Indeed, in some jurisdictions, constitutional litigation has resulted in courts concluding that these so called second generation rights are, in fact, judicially enforceable. $^{3}$

During recent years, the Constitutional Court of Peru has reviewed several cases involving the right to health. In doing so, the Court has examined aspects of the right to health, analyzing elements of its normative content and outlining, in particular, the obligation of progressive realization. Through interpretations carried out in four different cases, the Court has set out important judicial precedents regarding the implementation of the right to health. The purpose of this paper is to explore and comment on these developments.

This paper begins with a preliminary explanation of the human right to health in international human rights law. It then reviews the concept of progressive realization and the corresponding prohibition of regression. The paper then follows with an examination of case law from the Constitutional Court of Peru where the scope of this right is addressed.

\footnotetext{
${ }^{1}$ Justice Richard J Goldstone, 'Foreword' in Varun Gauri and Daniel M Brinks (eds), Courting Social Justice: Judicial enforcement of social and economic rights in the developing world (Cambridge University Press 2008) vii.

${ }^{2}$ Tara Melish, Protecting Economic, Social and Cultural Rights in the Inter-American Human Rights System: A Manual on Presenting Claims (Orville H. Schell, Jr. Center for International Human Rights Yale Law School and Centro de Derechos Económicos y Sociales 2003) 6.

${ }^{3}$ See eg, studies on judicial review in V Gauri and M Brinks (eds) Courting Social Justice, Judicial enforcement of social and economic rights in the developing world (Cambridge University Press, 2008), including countries such as Brazil, India, Nigeria, Indonesia and South Africa.
} 


\section{B. The Human Right to Health}

The right to the highest attainable standard of physical and mental health, henceforth referred to as 'the right to health', has been part of the rhetoric of human rights since the emergence of the first international declarations. For example, it was in 1946 that the World Health Organization declared in its Constitution that 'The enjoyment of the highest attainable standard of health is one of the fundamental rights of every human being without distinction of race, religion, political belief, economic or social condition'. ${ }^{4}$ Subsequently, in 1948, the Universal Declaration of Human Rights recognized that 'Everyone has the right to a standard of living adequate for the health and well-being of himself and of his family, including food, clothing, housing and medical care and necessary social services'. ${ }^{5}$ However, further precision in human rights law in respect to what the right to health means and what its full realization entails has only been given in recent years. Thus, it is fair to say that interpretative work concerning this right is relatively new and pioneering. ${ }^{6}$

A growing number of General Comments by various United Nations bodies show the existence of a growing interest in the normative development of the right to health in international spheres. The right to health is articulated in article 12.1 of the International Covenant on Economic, Social and Cultural Rights (ICESCR). This legal provision stipulates that 'the States Parties to the present Covenant recognise the right of everyone to the enjoyment of the highest attainable standard of physical and mental health'. The Committee on Economic, Social and Cultural Rights (CESCR or Committee), in charge of overseeing the implementation of the ICESCR, has clarified the content of the right to health and the obligations on states generated from it. Aside from these instruments, some other prominent comments include General Recommendation 24 of the Committee on the Elimination of Discrimination against Women on 'Women and Health' (1999); General

\footnotetext{
${ }^{4}$ Constitution of the World Health Organisation, Preamble. Adopted in New York (1946).

${ }^{5}$ Universal Declaration of Human Rights (1948) Article 25.

${ }^{6}$ World Health Organisation, Human Rights, Health and Poverty Reduction Strategies (2005).
} 
Comment 14 by the Committee on Economic, Social and Cultural Rights (CESCR) on 'the Right to Health' (2000); General Comment 3 of the Committee on the Rights of the Child on 'HIV/AIDS and Children's Rights' (2003). For his part, the former UN Special Rapporteur on the Right of Everyone to the Enjoyment of the Highest Attainable Standard of Physical and Mental Health, Paul Hunt, has complemented the work done by the Committee by providing important elaboration to further the understanding of this human right. In the words of Mr Hunt, the right to health can be understood as 'a right to an effective and integrated health system, encompassing health care and the underlying determinants of health, which is responsive to national and local priorities, and accessible to all'?

From this definition it can be established that the right to health is not equivalent to the right to be healthy, or the right to medical care. The right to health is not only about access to medical services and the provision of doctors, nurses and drugs. ${ }^{8}$ The right to health encompasses greater entitlements for human beings and places upon states greater responsibilities to fulfil certain obligations. The right to health also includes the right to underlying determinants of health, which in this case are defined as: adequate sanitation, safe drinking water and health education. Alongside these, the notion of accessibility is one of the main components of the right to health. As set out in Hunt's definition, the right to health is about an effective and integrated health system which must be 'accessible to all'. This means that the health system should be available to those living in poverty, majority ethnic groups and minority indigenous people, men and women living in urban settings and in remote villages, and anyone else for whom the state is responsible.

\footnotetext{
${ }^{7}$ Paul Hunt, Report of the Special Rapporteur on the Right of Everyone to the Enjoyment of the Highest Attainable Standard of Physical and Mental Health E/CN.4/2006/48, March 2006.

${ }^{8}$ ibid.

${ }^{9}$ ibid.
} 


\section{The Principle of Progressive Realisation: the Obligation upon States to Progressively Realise the Right to Health}

Like other economic, social and cultural rights, such as the right to education $^{10}$ and the right to an adequate standard of living, ${ }^{11}$ the right to health is subject to progressive realization and resource availability. As set out in article 2 of the ICESCR, 'Each State Party undertakes to take steps $\ldots$ to the maximum of its available resources, with a view to achieving progressively the full realization of the rights recognized in the present Covenant'.

Inevitably, for countries with significant resource constraints, immediate and absolute satisfaction of the material conditions for the enjoyment of the right to health is not an easy task and the principle of progressive realization originates in response to that fact. According to the principle of progressive realization, a state is to prioritize in order to advance implementation of the rights in the ICESCR to the fullest extent of the state's capacity within a reasonable time. In the words of the CESCR, in recognition of the fact that full realization of these rights cannot be achieved in a short period of time, a certain amount of flexibility is required, 'reflecting the realities of the real world and the difficulties involved for any country in ensuring full realization of economic, social and cultural rights'. ${ }^{12}$ Nonetheless, it continues, 'the fact that realization over time, or in other words progressively, is foreseen under the Covenant should not be misinterpreted as depriving the obligation of all meaningful content. ${ }^{, 13}$ This means that this principle must be read in light of the overall objective of the ICESCR, according to its rationale, which is to establish clear obligations for States Parties to move as quickly as possible towards full realization of the rights contained therein. ${ }^{14}$

Based on the requirement of progressiveness, the authorities must undertake significant efforts and demonstrate a continued commitment towards the progressive realization of these rights, including, of course,

\footnotetext{
${ }^{10}$ International Covenant on Economic, Social and Cultural Rights (1966) Article 13.

11 ibid Article 11.

12 Committee on Economic, Social and Cultural Rights (CESCR) General Comment $N^{\circ} 3,14 / 12 / 90$, The nature of States parties obligations (1990) para 9.

13 ibid.

14 ibid.
} 
the right to health. The ICESCR imposes on states 'the obligation to move as expeditiously and effectively as possible ${ }^{15}$ and therefore states must employ all appropriate means, including legislative measures and policies and implement appropriate mechanisms that demonstrate a real commitment in this regard. For example, under the principle of progressive realization in the context of the right to health, a state may decide to increase by $20 \%$ the number of births attended by health professionals in the next five years. States could also, for example, set a goal of reducing infant mortality rates in rural areas over the next three years.

In addition, all States Parties to the Covenant are obliged to respect the right to health, and in that sense, they must make all the resources possible available for this purpose, even when their level of economic development is not high. In this sense, it is worth observing that often the obstacles to improving health protection have more to do with poor allocation, distribution or efficiency in the management of available resources $^{16}$ than the lack of resources. With regard to this situation, the Limburg Principles on the Implementation of the International Covenant on Economic, Social and Cultural Rights recognizes that 'the obligation of progressive achievement ... requires efficient use of available resources'. ${ }^{17}$

For its part, the Committee has indicated that the implementation of many measures to concretize the right to health can take place without the need for large financial expenditure, but rather through actions that involve minimal financial implications; for example, through the adoption, amendment or repeal of laws and dissemination of information on public health. ${ }^{18}$ This idea finds support in General Comment 3 regarding the Nature of the Obligations of States Parties, which states that

\footnotetext{
15 ibid.

${ }^{16}$ Virginia A Leary 'The Right to Health in International Human Rights Law' (1994) 1 Health and Human Rights 24.

17 The Limburg Principles on the Implementation of the International Covenant on Economic, Social and Cultural Rights (1987) principle 23.

${ }^{18}$ Committee on Economic, Social and Cultural Rights (CESCR) General Comment $\mathrm{N}^{\circ} 14,11 / 08 / 2000$. The right to the highest attainable standard of health (article 12 of the

International Covenant on Economic, Social and Cultural Rights) E/C.12/2000/4 (2000) para 18.
} 
'even in times of severe resources constraints whether caused by a process of adjustment, of economic recession, or by other factors the vulnerable members of society can and indeed must be protected by the adoption of relatively low-cost targeted programmes'. ${ }^{19}$

\section{The Prohibition of Regression}

The natural corollary of the notion of progressive realization is the prohibition of regression. That is, in conjunction with states undertaking to achieve progressively the full realization of economic, social and cultural rights, they also assume an obligation not to retreat from the levels of protection already achieved through legislation and other legal or policy measures. In this sense, we can speak of violations of the obligation of progressive realization contained in the Covenant when the government deliberately introduces retrogressive measures to restrict or reduce the level of enjoyment of rights already achieved.

Courtis speaks of two possible fields of application of the prohibition of regression. ${ }^{20}$ He refers to regression of results - that is, when the results of a particular measure or policy decline in comparison to an earlier stage. Courtis also discusses the concept of normative regression, which applies to the extension of the rights or entitlements provided by legal norms. To verify that normative regression exists, comparison will have to be made with the standard that it has modified or replaced to determine whether the later norm dismisses, limits or restricts any rights or benefits granted by the previous one.

To illustrate the prohibition of regression of results, we can look at the Special Rapporteur on the Right to Health's final report regarding his visit to Peru in $2004,{ }^{21}$ where he observed that Peru's expenditure on public health was low in comparison with other countries in the region and that it had declined from 95 Peruvian New Soles per capita in 2001 to 78 Peruvian New Soles in 2003. Moreover, he noted that 'budget allocations for health care to richer and poorer regions have reportedly

\footnotetext{
${ }^{19}$ CESCR (n 12) para 12.

${ }^{20}$ Christian Courtis (ed) Ni un paso atrás. La prohibición de regresividad en materia de derechos sociales (Editores del Puerto 2006).

${ }^{21}$ Paul Hunt Report of the Special Rapporteur on the Right of Everyone to the Enjoyment of the Highest Attainable Standard of Physical and Mental Health, Mission to Peru E/CN.4/2005/51/Add.3, (February, 2005).
} 
been inequitable'. ${ }^{22}$ In his view, this decline in expenditure represented an unjustified regression that violated Peru's international obligation of progressive realization within maximum available resources, as enshrined in the ICESCR.

Regarding the prohibition of regression, the CESCR states in General Comment 3 that if a state implements a retrogressive measure, it must justify the action in the context of the full use of maximum available resources. $^{23}$ Such a duty of justification has been expressed by the CESCR in the context of the right to health as follows:

As with all other rights in the Covenant, there is a strong presumption that
retrogressive measures taken in relation to the right to health are not
permissible. If any deliberately retrogressive measures are taken, the State
party has the burden of proving that they have been introduced after the most
careful consideration of all alternatives and that they are duly justified by
reference to the totality of the rights provided for in the Covenant in the
context of the full use of the State party's maximum available resources. ${ }^{24}$

Therefore, in light of the guidelines laid down by the CESCR, it can be said that, as a matter of principle, retrogressive measures are impermissible. State social policies should be geared to the progressive development of the conditions necessary to maximize enjoyment of these rights, not to backsliding on international human rights commitments. Failure to adopt a policy of progressive realization would be contrary to the overall objective of the Covenant. Regressive measures, however, are permissible under the CESCR's interpretation of the Covenant in General Comment 14, but only under exceptional circumstances. The responsibility remains with the state to prove that such measures were taken as a matter of 'last resort', that is, after careful consideration of all alternatives and in the context of the full use of maximum available resources. $^{25}$

\footnotetext{
22 ibid para 36.

${ }^{23}$ CESCR (n 12) para 9.

${ }^{24}$ CESCR (n 18) para 32.

${ }^{25}$ Julieta Rossi 'La Obligación de no regresividad en la jurisprudencia del Comité de Derechos Económicos, Sociales y Culturales' in Christian Courtis (ed) Ni un paso atrás. La prohibición de regresividad en materia de derechos sociales (Editores del Puerto, 2006) 91.
} 
Regarding the right to health, the Committee has been clear in stating that under no circumstance can a state justify its non-compliance with the 'core obligations' which are non-derogable. ${ }^{26}$ In compliance with 'core obligations', states are expected to ensure the satisfaction of, at the very least, minimum essential levels of each of the rights recognised in the ICESCR, ${ }^{27}$ that is, a minimum core content. In the words of Rossi, 'the minimum content of a right refers to essential elements or basic features without which the right is denatured or becomes unrecognizable', ${ }^{28}$ that is, a minimum base or irreducible component that all people in all settings must be guaranteed. For Courtis, 'the obligation to comply with the minimum core content is a priority to cover the basic needs of individuals and groups who are not able to afford them by themselves'. ${ }^{29}$ In the CESCR's view, expressed in paragraph 43 of General Comment 14 , core obligations in the case of the right to health include, at least, the obligation to provide essential primary health as well as access to health facilities, goods and services on a non-discriminatory basis, especially for vulnerable or marginalized groups, among other obligations. ${ }^{30}$ Regressive

${ }^{26}$ CESCR (n 18) para 47.

${ }^{27}$ CESCR (n 12) para 10.

${ }^{28}$ Rossi (n 25) 95 (author's translation).

${ }^{29}$ Courtis (n 20) 11 (author's translation).

${ }^{30}$ CESCR (n 18) para 43. 'In General Comment No. 3, the Committee confirms that States parties have a core obligation to ensure the satisfaction of, at the very least, minimum essential levels of each of the rights enunciated in the Covenant, including essential primary health care. Read in conjunction with more contemporary instruments, such as the Programme of Action of the International Conference on Population and Development, $(\underline{28})$ the Alma-Ata Declaration provides compelling guidance on the core obligations arising from article 12. Accordingly, in the Committee's view, these core obligations include at least the following obligations:

(a) To ensure the right of access to health facilities, goods and services on a nondiscriminatory basis, especially for vulnerable or marginalized groups;

(b) To ensure access to the minimum essential food which is nutritionally adequate and safe, and to ensure freedom from hunger;

(c) To ensure access to basic shelter, housing and sanitation, and an adequate supply of safe and potable water;

(d) To provide essential drugs, as periodically defined under the WHO Action Programme on Essential Drugs;

(e) To ensure equitable distribution of all health facilities, goods and services;

(f) To adopt and implement a national public health strategy and plan of action, on the basis of epidemiological evidence, addressing the health concerns of the whole population; the strategy and plan of action shall be devised, and periodically reviewed, on the basis of a participatory and transparent process; they shall include 
measures that dismantle the minimum content of the rights contained in the Covenant, including the right to health, are, in all circumstances, impermissible.

\section{The Correlation between 'Available Resources' and Progressive Realization}

The correlation between the availability of financial resources and the obligation of progressive realization has interesting implications that are worth commenting upon. ${ }^{31}$ From a comparative perspective, the notions of resource availability and progressive realization have two crucial implications. First, a state's obligations concerning the right to health will vary depending on its stage of economic development. Due to the differences in resource wealth, developed countries' performance expectations will be higher than those of developing nations. It is reasonable to think that if the available resources in a country are considerably more than in others, the level of obligation on this State should be relatively higher in comparison to lower income countries. Thus, due to marked asymmetries in the levels of economic development around the world, enforcement of minimum standards of universal application across nations is a difficult task. Nonetheless, this task may be facilitated by a comparative analysis. For example, by comparing different countries with substantially equivalent levels of economic development it is possible to estimate, roughly, which countries have vigorously committed themselves to make significant progress in realizing the right to health, proving that maximum available resources have been used to this end.

For example, Bolivia, one of the poorest countries in Latin America, has incorporated the principle of health as a fundamental human

\footnotetext{
methods, such as right to health indicators and benchmarks, by which progress can be closely monitored; the process by which the strategy and plan of action are devised, as well as their content, shall give particular attention to all vulnerable or marginalized groups.'

31 These reflections are based on the thoughts given by Paul Hunt during the short course Understanding Women's Rights held at The London School of Economics and Political Science (LSE) in May 2008. See alsoPaul Hunt, WHO workshop on indicators for the right to health. A background note (2003) Available online at: $<$ http://www.who.int/hhr/activities/en/Background_paperby $\% 20 \mathrm{Paul} \% 20 \mathrm{Hunt} \% 20 \mathrm{rev}$ ised.pdf $>$ (accessed 25 June 2012).
} 
right in its national social development plan, and, in turn, is implementing policies towards attaining a higher level of health and education among its population. Despite financial constraints, Bolivia has implemented a universal maternal and child health insurance policy and has made significant progress in improving health coverage in the poorest areas in the Bolivian Andes. ${ }^{32}$ A comparative look at countries at a similar stage of economic development would allow us to evaluate whether or not an optimum level of progress in socio-economic rights has been achieved and to what extent political leadership (in addition to financial capacity) has been a contributing factor. Similarly, there is a significant difference in the statistics concerning health status among high-income countries. For example, in 1991, the United States had an infant mortality rate of nine per 1,000 live births, while the rate in Japan and Switzerland (countries with similar levels of income per capita) was considerably better, with five deaths per 1,000 births.

Second, in view of the principle of progressive realization, the obligation of the state in relation to the right to health will vary over time. This means that what was seen as a step forward 10 years ago might not be sufficient to comply with current minimum standards. It is thus apparent that there is a variable component in obligations regarding the right to health that will require continuous monitoring. As argued by the ex-UN Special Rapporteur on the Right to Health, indicators and benchmarks have a major role to play in measuring and monitoring the progressive realization of the right to health, especially in the context of emerging economies. ${ }^{33}$

Finally, it is worth noting that the principle of progressive realization also bears on the relationship between developed and developing nations. One aspect of developed countries' obligation to protect and respect human rights is to engage in international assistance and cooperation. ${ }^{34}$ Unquestionably, the state has the primary

\footnotetext{
32 Nila Heredia, Plan de Desarrollo de la Salud 2006-2010 (unpublished presentation).

${ }^{33}$ Paul Hunt, WHO workshop on indicators for the right to health: A background note (2003)

$<\mathrm{http}: / /$ www.who.int/hhr/activities/en/Background_paperby\%20Paul\%20Hunt $\% 20 \mathrm{rev}$ ised.pdf $>$ accessed on 24 September 2012.

${ }^{34}$ CESCR (n 12) para 13.
} 
responsibility of respecting, protecting and fulfilling the human rights of all those who are within its territory; however, international human rights law also imposes the obligation on states to look beyond their own borders and engage in international cooperation and assistance. For instance, article 2.1 of the ICESCR stipulates that 'Each State Party to the present Covenant undertakes to take steps, individually and through international assistance and co-operation, especially economic and technical, to the maximum of its available resources, with a view to achieving progressively the full realization of the rights recognized in the present Covenant ...' Moreover, declarations from world conferences have reinforced these principles of international assistance and cooperation. At the UN World Summit in September 2005, 170 Heads of State and Government committed themselves to improving health systems in developing countries and those with economies in transition, with the aim of providing sufficient health workers, infrastructure, management systems and supplies to achieve the health-related Millennium Development Goal by $2015 .^{35}$

\section{Domestic Judicial Review of the Principle of Progressive Realization: the Case of the Constitutional Court of Peru}

Article 2 of the Peruvian Constitution of 1993 spells out certain fundamental rights, including the right to life, equality before the law, freedom of conscience and religion, freedom of association and assembly, among other rights. In spite of its interconnection with other rights contained in article 2, such as the right to life and the right to physical integrity, the right to health is not mentioned in this section. The right to health is instead found in Chapter II of the Constitution under the section on Social and Economic Rights. Within this section, article 7 recognizes the 'right of everyone to the protection of their health'. In addition to this provision, article 9 emphasizes the responsibility of the state to define a national health policy, with it being the executive's responsibility to direct its implementation. The national health policy is implemented in a decentralized and pluralistic manner in order to provide equitable access to health services to all. Article 11 stipulates that 'the State guarantees

\footnotetext{
${ }^{35}$ World Summit Outcome (2005) paras 57(a) and 68(i), cited in Paul Hunt (n 7), 12.
} 
free access to health services ... through public, private or mixed enterprises, and it also oversees their efficient operation. ${ }^{36}$

Article 55 of the Peruvian Constitution states that 'Treaties concluded by the State and in force are part of national law'. With specific reference to human rights, the Fourth Final and Transitory Provision of the Constitution, enacted in 2004, states that 'Rules concerning the rights and freedoms recognized by this Constitution are construed in accordance with the Universal Declaration of Human Rights and international treaties and agreements on those rights, which have been ratified by Peru'. In that sense, the interpretation of a specific human right requires consideration of its content and obligations resulting from its recognition in international human rights treaties to which the Peruvian state is a party. In the case of the right to health, this will have to be done, particularly, in light of the ICESCR, ratified by Peru in 1978 .

During recent years, the Constitutional Court of Peru has considered cases that concern the right to health. In doing so, the Court has examined aspects of the right to health and determined which elements of its normative content are subject to judicial review. The following sections examine the arguments advanced in enforcing the right to health and the extent to which the Court has considered and analyzed protection standards developed internationally. In four cases in particular the Constitutional Court has addressed the scope of this right, as well as the range of international obligations arising from it in pursuit of its implementation: decision 2945-2003 Exp-AA/TC (HIV/AIDS); decision 2002-2006-PC/TC (La Oroya); decision 3081-2007-PC/TC (Mental Health); and decision 03477-2007-PA/TC (Non-regressivity).

\section{The Meaning of the Right to Health and its Connection with Other Fundamental Rights}

As is clear from the review of international law set out in the first section of this article, the right to health is not equivalent to the absence of disease or the right to be healthy. The right to health must be understood rather as the right of access to a range of facilities, goods, services and conditions necessary to achieve, progressively, the highest

\footnotetext{
36 See Political Constitution of Peru, 1993 at http://www.congreso.gob.pe/ _ingles/CONSTITUTION_29_08_08.pdf (accessed 25 June 2012).
} 
possible level of health. To that end, and going beyond mere medical assistance, the state is responsible for implementing a series of concrete measures and ensuring certain material conditions necessary for the enjoyment of good health. This must be achieved on the basis of equitable criteria in order to ensure that these facilities, goods, and services are made accessible in a manner free from discrimination.

In a case concerning mental health, judgment 3081-2007-PC/TC, the Constitutional Court followed this line of reasoning in interpreting the right to health. In this decision the Court stated:

Seen from the international law of human rights, health should not be understood as a right which requires the State to guarantee all its subjects the normal functioning of their organ systems, including the physical, biological and psychological, but rather as one that guarantees access to adequate health services, of good quality, with competent doctors and coherent public policies. However, from a constitutional perspective, the above led the supreme interpreter of the Constitution to the conclusion that health cannot be understood from a negative perspective, related to the absence of sickness, but it also requires a positive facet, in the sense that all have ... the right to be assigned health and social measures relating to food, clothing, housing and medical care, corresponding to the levels allowed by public resources and solidarity of the community. ${ }^{37}$

When deciding on a petition against the Ministry of Health to provide medical care to an HIV/AIDS patient in the case 2945-2003$\mathrm{AA} / \mathrm{TC}$, the Constitutional Court emphasized the intrinsic connection between the right to health and the fundamental right to life. This interpretation is consistent with the CESCR's General Comment 14, which stresses the indivisibility and interdependence of the right to health as it is 'closely connected with the exercise of other human rights and depends on these rights', referring specifically to the 'right to food, housing, employment, education, human dignity, life, nondiscrimination, equality, not to be subjected to torture, privacy, access to information and freedom of association, assembly and movement'. For the Committee, these and other rights and freedoms address integral components of the right to health.

In the HIV/AIDS case, the Constitutional Court explained the notion of interconnectivity in the following terms:

${ }^{37}$ [2007] 3081-2007-PC/TC para 19 (author's translation - emphases added). 
Health is a fundamental right due to its inseparable relationship with the right to life, and the link between the two rights is insoluble, since the presence of a disease or condition can lead to death or, in any case, impair the quality of life. ${ }^{38}$

Furthermore the Court added that:

... with no education, health and decent quality of life in general, we can hardly speak about freedom and social equality, which makes both the legislature and the administration of justice think about recognizing these rights together and interdependently. ${ }^{39}$

The Court's judgment in the HIV/AIDS case is of significant value since the Court fully adopts the approach of protecting the right to health by means of its connection with other fundamental rights and freedoms. By illuminating the right to health's intrinsic connection with the right to life and other fundamental rights, the Court opens a window for legal protection of the right to health through the protection of related constitutionally recognised fundamental rights. ${ }^{40}$ In this sense, the Court states:

While the legal right to health is not included among the fundamental rights established in Article 2 of the Constitution ['Fundamental Rights'], but rather is recognized in the chapter on social and economic rights referred to in articles 7 and 9 of the Constitution, this Court ... considers that where the infringement of the right to health involves other fundamental rights like the right to life, physical integrity and the free development of personality, this right becomes a fundamental right and, therefore, its infringement deserves protection via a write of Amparo. ${ }^{41}$

\section{The Clause of 'Progressivity'}

The Committee has emphasized that the 'progressive realization of the right to health over a period of time' implies a specific and continuing obligation to move as expeditiously and effectively as possible towards the goal of full realization of the right to health. ${ }^{42}$ Unarguably, the broad and complex nature of the right to health, coupled with a margin of

\footnotetext{
38 [2003] 2945-2003-AA/TC para 28 (author's translation).

${ }^{39}$ ibid para 11 (emphasis added).

${ }^{40}$ Although, as stated in judgment 3081-2007-AA/TC para. 23, judicial protection requires a finding of seriousness and reasonableness.

${ }^{41}$ Remedy for the protection of rights stated in article 2 of the Peruvian Constitution of 1993 (para 6).

${ }^{42}$ CESCR (n 12) para 9.
} 
discretion left to states under the principle of progressive realization, has helped to build a general impression that this right is difficult to define and even more difficult to enforce judicially.

In practice, the principle of progressive realization is used by governments to assert budgetary constraints as a legitimate justification for not complying with their obligations under international law. In many jurisdictions, including Peru, socio-economic rights, including the right to health, are considered 'programmatic rights', confined to the field of public policy where sufficient budgetary support is required for implementation. This argument is premised on the belief that these rights require the deployment of specific governmental measures, but they do not confer a right which can be claimed per se. This interpretation was adopted, for example, by the Ministry of Health of Peru in the HIV/AIDS case, where the Ministry argued that 'according to Articles 7 and 9 of the Constitution, the right to health and the national health policy program are rules which represent a mere plan of action for the State, rather than a concrete right'. ${ }^{43}$

In its judgment in the Mental Health case, the Constitutional Court ruled that the right to health is not a programmatic right but rather a concrete and justiciable right when the conditions surrounding the claim are sufficiently serious, the claim is reasonable, it is connected to or affects other rights, and the state has resources available to address the situation. ${ }^{44}$ Specifically, the Court noted in the Mental Health case that:

Despite the progressive nature of the right to health in terms of budgetary possibilities, it should be taken into account, in order to arrive at a valid decision, that the enforceability of a social right always depends on three factors: a) the seriousness and reasonableness of the case, b) its relationship with other fundamental rights, and c) budget availability ... ${ }^{45}$

Nonetheless, in the same decision, the Court explained that because of the right to health's close connection with the right to life, 'budget constraints cannot be an obstacle or a valid argument for denying a person health

\footnotetext{
${ }^{43}$ HIV/AIDS (n 38) Antecedents.

${ }^{44}$ CIES and CLADEM Jurisprudencia sobre la protección del derecho a la salud en cuatro países andinos y en el Sistema Interamericano (Ediciones Nova Print SAC. 2007) 211.

${ }^{45}$ Mental Health (n 37) para 23.
} 
benefits, so as to jeopardize their right to life'. ${ }^{46}$ Furthermore, the Court created valuable precedent in this decision by recognizing the right to health as a 'constitutional right of unquestionable character, ruling out discretion'.

The Constitutional Court has also declared a new vision of socioeconomic rights which involves setting aside the programmatic conception, calling instead for an understanding that specific duties and obligations derive from these rights. In this regard, the Court has stated:

Although it is true that the effectiveness of social rights requires a minimum of state action through the establishment of public services, as well as of society through the contribution of taxes, since all social policy requires a budget execution, it is also true that concrete obligations to be met result from these rights, so that States should adopt consistent and effective measures in order to achieve progressively the full realization of these rights in conditions of equity for the entire population. ${ }^{48}$

Through judgments like the HIV/AIDS case, the Court has clarified that the principle of progressivity cannot be understood as providing the state with an indefinite time within which to undertake measures, and in this way justify state inaction. That is, the principle does not amount to a state's prerogative by which it may delay indefinitely efforts to ensure the full realization of socio-economic rights. On the contrary, as discussed below, the Court states that the ICESCR establishes the obligation to take concrete steps leading to the full realization of the right to health, which must be implemented within a reasonable time. Thus, the Court stated that:

... the principle of progressivity in the expenditure referred to by the Eleventh Transitional and Final Provision of the Constitution, cannot be understood with vagueness and, thus, serve as a common argument for inaction of the State, because for this Court the progressiveness in spending does not exempt the State from observing the establishment of reasonable timeframes nor specific and ongoing actions to implement public policies.

What has been declared at the Eleventh Transitional and Final Provision of the Constitution is consistent with Article 2.1 of the [International] Covenant on Economic, Social and Cultural Rights, which requires that States commit themselves to adopt measures to the maximum of available resources to achieve,

\footnotetext{
${ }^{46}$ ibid para 23.

47 ibid para 24.

${ }^{48}$ HIV/AIDS (n 38) para 12.
} 
progressively, the full realization of rights recognized in the Covenant, including health. It is clear that the Peruvian State cannot be exempt from this duty, nor to assume it as a management ideal, since it is an urgent obligation to be fulfilled, albeit gradual, always accompanied by reasonable deadlines and concrete actions. $^{49}$

By clarifying the import of the notion of progressivity, the Peruvian Constitutional Court has contributed to the consolidation of the notion of judicial enforcement of the right to health. The position that the right to health is judicially enforceable rejects the argument that the right to health is purely 'programmatic', associated with a declaration of good intentions. Whilst the Constitutional Court acknowledges that the immediate fulfillment of the right to health is difficult for a developing country like Peru, it also asserts that such justification is only tolerable if concrete actions to advance its fulfillment are also in place.

\section{The Prohibition of Regression or 'Obligation of Non-Regressive Actions'}

The correlative prohibition of regression, also known as the 'obligation of non-regressivity' follows from the duty of 'progressivity'. The CESCR's General Comment 14 specifically highlights the obligation not to take 'deliberately retrogressive' actions in relation to the right to health, unless it is clear that they were chosen 'after the most careful consideration of all alternatives and that they are duly justified by reference to all the rights enshrined in the Covenant in relation to the full utilization of the maximum resources available to the State Party'.

In the Non-regressivity case, the Peruvian Constitutional Court invokes the principle within the context of the ICESCR, stating:

... we must remember that, when in Article 2.1 of the International Covenant on Economic, Social and Cultural Rights (ICESCR) it establishes that 'each of the States Parties to the present Covenant undertakes to take steps, individually and through international assistance and cooperation, especially economic and technical, to the maximum of its available resources to achieving progressively, by all appropriate means, including particularly the adoption of legislative measures, the full realization of the rights recognized', thus it establishes an obligation of progressivity from which follows a ban on regression. ${ }^{50}$

\footnotetext{
49 ibid paras 36 and 37.

${ }^{50}$ [2007] 03477-2007-PA/TC para 17 (author's translation).
} 
Interestingly, Courtis notes that in Portugal, the prohibition of regression in connection with health services has also been examined at the constitutional level. ${ }^{51}$ The Constitutional Court of Portugal declared, in a challenge to a law that repealed a previous law that established the National Health Service, that the constitutional right to health expressly imposes an obligation on the government to establish a national health service and that the repeal of that statute was unconstitutional. In its resolution, the Portuguese Court stated:

If the State does not comply with the due realization of concrete and determinate constitutional tasks that it has in charge, it can be held responsible for a constitutional omission. However, when the State undoes what it had already done to comply with those tasks, and thus affects a constitutional guarantee, then it is the State action which amounts to a constitutional wrong. If the Constitution imposes upon the State a certain task - the creation of a certain institution, a certain modification of the legal order - then, when that task has already been complied with, its outcome becomes constitutionally protected. The State cannot move backwards - it cannot undo what it has already accomplished, it cannot go backwards and put itself again in the position of debtor ...

Generally, social rights translate themselves in a duty to act, especially a duty to create public institutions (such as the school system, the social security system, et cetera). If these institutions are not created, the Constitution can only give ground to claims for their creation. But, after they have been created, the Constitution protects their existence, as if they already existed when the Constitution was adopted. The constitutional tasks imposed on the State as a guarantee for fundamental rights, consisting in the creation of certain institutions or services, do not only oblige their creation, but also a duty not to abolish them once created. This means that, since the moment when the State complies (totally or partially) the constitutionally imposed tasks to realize a social right, the constitutional respect of this right ceases to be (or to be exclusively) a positive obligation, thereby also becoming a negative obligation. The State, which was obliged to act to satisfy a social right, also becomes obliged to abstain from threatening the realization of that social right. ${ }^{52}$

${ }^{51}$ International Commission of Jurists (ICJ) Courts and the Legal Enforcement of Economic, Social and Cultural Rights: Comparative Experiences of Justiciability (Geneva, 2008).

${ }_{52}$ Portuguese Constitutional Tribunal, Decision (Acórdão) No 39/84, April 11, 1984 cited in: ICJ (n 51) 32-33. 


\section{Obligations of Immediate Effect: Taking Action and Adopting Measures within a Reasonable Time}

In General Comment 14, the Committee emphasizes that the right to health imposes immediate obligations on states to (i) guarantee that the right will be implemented without discrimination of any kind and (ii) take deliberate and concrete measures toward 'the full realization of the right to health'.

These obligations are of great importance for the purpose of justiciability, since, being obligations of an immediate nature they create clear standards for judicial review. For example, the enactment or nonremoval of discriminatory legislation that deliberately leads to inequalities in the enjoyment of this right is a clear breach of the nondiscrimination aspect of the obligation of immediate effect. Likewise, the obligation to take action includes the duty to adopt legislative, administrative, financial, educational and social measures as well as to provide judicial remedies. ${ }^{53}$ This obligation counters the argument that the right to health is merely 'programmatic' and thus left to the discretion of political powers and pending available resources.

In the case 2002-2006-PC/TC, regarding environmental pollution from mining activities in La Oroya, the Peruvian Constitutional Court emphasized the notion of 'reasonable time' within which to take concrete and efficient actions to implement policies for realizing the right to health. After addressing the situation of neglect and urgency in the case which concerned high levels of pollution produced by mining operations in the area, affecting the population's health, and which had been ongoing for seven years - the Court imposed a time limit for the public health authorities to implement an emergency health system. This was one of the most important aspects of this judgment, with the Court stating:

... It is not valid to argue that the protection of this fundamental right, due to its dimension as a social right, should be deferred in time pending certain state policies. Such protection must be immediate, as the serious situation facing children and pregnant women who have been contaminated requires from the state a concrete, dynamic and efficient intervention, since in this case, the right to health is presented as an enforceable right, and as such, is of unavoidable attention. It must be therefore ordered by the Ministry of Health that within 30

${ }^{53}$ CESCR (n 12) paras 3 to 5. 
days an emergency health system shall be implemented to attend to persons contaminated with lead in the town of La Oroya in order to achieve immediate recovery. $^{54}$

The judicial review carried out in the La Oroya case, as well as in previous cases, has led to well-reasoned conclusions that clarify the content of the human right to health and the nature of the state's obligations.

\section{E. Conclusion}

The right to health does not entail the absence of disease or the right to be healthy. Since good health cannot be guaranteed by the State, the right to health must be understood rather as the right to enjoy a range of facilities, goods, services and conditions necessary to achieve, progressively, the highest level of health. For this purpose, and going beyond mere medical assistance, the State is responsible for implementing a series of concrete measures to secure certain socio-economic conditions that enable the population to enjoy optimal health, including a criterion of equity.

From the cases reviewed, it is argued that the Constitutional Court of Peru has elucidated - with the correct criteria - the often misunderstood principle of progressive realisation. The Court explains that the principle should not be understood as indeterminate and thus justifying state inaction, but rather, should be understood as requiring the deployment of concrete and effective measures for the progressive realization of the right. Moreover, the Court leaves aside a programmatic vision of the right to health, ruling instead that specific obligations arising from the right demand compliance within reasonable deadlines. Rightly, 'reasonable time' was highlighted in the La Oroya case, where the Court interpreted the principle of progressive realization as mandating a specific timeframe for the implementation of a concrete measure in the field of environmental health, which had previously been mired in excessive delay.

Importantly, by clarifying the sense of the notion of progressivity, the Court contributes valuable jurisprudence regarding the enforceability of the right to health in domestic jurisdictions. This helps to overcome the typical constraints based on the principle of progressivity and the notion

\footnotetext{
${ }^{54}$ [2006] 2002-2006-PC/TC para 61 (author's translation, emphasis added).
} 
of the right to health as a norm of purely programmatic character, which ignore the range of obligations prescribed by international law that generate clear and concrete standards of judicial review. In particular, the core obligations outlined in General Comment 14, aimed at ensuring the satisfaction of minimum essential levels of the right to health, establish a framework for the justiciability of the right to health. Similarly, the general obligation of immediate effect, linked to the obligation of progressive realization and thus to the prohibition of regression, also provides an important parameter for justiciability. In sum, the Constitutional Court of Peru has established important judicial precedents regarding the implementation of the right to health, adding to the record of jurisdictions worldwide that have adjudicated economic, social and cultural rights in domestic courts. 